\title{
GAMBARAN PENGETAHUAN MASYARAKAT KAMPUNG KULUR II MENGENAI PERTOLONGAN PERTAMA PADA KEJADIAN KECELAKAAN LAUT
}

\section{DEMONSTRATION THE COMMUNITY KNOWLEDGE ABOUT FIRST AID OF MARRINE ACCIDENT IN KULUR II VILLAGE, SANGIHE REGION, NORTH SULAWESI}

\author{
Meistvin Welembuntu, Sherina Jelien Manoppo, Iswanto Gobe \\ Program Studi Keperawatan, Jurusan Kesehatan
}

Email: meistvin@yahoo.com

\begin{abstract}
Abstrak: Kecelakaan dapat terjadi di mana saja menenimbulkan rasa kaget, dan dapat menyebabkan kepanikan. Adanya rasa panik dapat menyebabkan korban baru sehingga dibutuhkankan suatu ketenangan. Pemberian pertolongan pertama pada korban kecelakaan adalah satu hal yang paling penting, karena dengan penanganan secara cepat akibat yang fatal dapat dihindarkan. Tujuan penelitian ini yaitu diketahuinya tingkat pengetahuan masyarakat Kampung Kulur II mengenai pertolongan pertama pada kejadian kecelakaan laut. Penelitian ini menggunakan desain penelitian deskriptif untuk mengetahui tingkat pengetahuan. Hasil nya menunjukkan tingkat pengetahuan responden terbanyak yaitu 55\% memiliki pengetahuan cukup, 42,5\% memiliki pengetahuan baik, dan kurang pengetahuan sebanyak 2,5\%. Diharapkan pihak pemerintah daerah dan tenaga Kesehatan lebih aktif lagi dalam peningkatan pengetahuan masyarakat,
\end{abstract}

Kata kunci: Kecelakaan laut, Pertolongan Pertama, Pengetahuan

\begin{abstract}
Accidents can happen anywhere causing shock and panic. Panic can cause new victims so it needs calmness. First aid to accident victims is one of the most important things because with rapid treatment fatal consequences can be avoided. The purpose of this study wants to know the level of knowledge of the people at Kulur II village to perform first aid in marine accidents. The method used was a descriptive research design to determine the level of knowledge. The results showed that $55 \%$ of respondents have a sufficient level of knowledge, $42.5 \%$ of respondents have good knowledge, and $2.5 \%$ of respondents have less knowledge. The local government, as well as health workers, should be more active to improve the community's knowledge in terms of how to perform first aid.
\end{abstract}

Keywords: Marine accident, first aid, knowledge

\section{PENDAHULUAN}

Kecelakaan dapat terjadi di mana saja menenimbulkan rasa kaget, dan dapat menyebabkan kepanikan. Adanya rasa panik dapat menyebabkan korban baru sehingga dibutuhkankan suatu ketenangan dan keterampilan. Pemberian pertolongan pertama pada korban kecelakaan adalah satu hal yang paling penting, karena dengan penanganan secara cepat akibat yang fatal dapat dihindarkan. Teknik yang digunakan untuk menyelamatkan berprinsip pada ketenangan untuk dapat bertindak, dengan ketenangan dapat dipilih cara penanganan secara tepat. (Wastd, 2006)

Kecelakaan atau kejadian yang tidak diinginkan dapat berupa suatu insiden kecil atau suatu bencana yang melibatkan penderita dalam jumlah besar. Bencana yang baru akan terjadi bila korban tidak mendapatkan pertolongan yang baik dengan segera, orang yang akan memberikan pertolongan adalah mereka yang berada di tempat kejadian atau anggota keluarga dari korban tersebut. Mereka yang berupaya memberikan pertolongan pertama memiliki berbagai tingkat pengetahuan mulai dari tidak ada sampai mereka yang mungkin sudah terlatih. (Sarana et al., 2009)

Menurut survey di Kampung Kulur, masyarakat Kampung Kulur banyak yang beraktifitas di pantai di karenakan lokasi pantai yang dekat dengan tempat tinggal warga, sebagian masyarakat bermata pencaharian nelayan, kegiatan yang dilakukan setiap sore ada yang pergi ba giop atau mencari ikan yang terdiri dari 5 sampai 10 orang, ada sekelompok anak-anak yang mandi di pantai, juga saat air naik ada yang memancing dari Talud. Tahun 2019 terdapat 2 orang yang meninggal dengan kasus tenggelam yang tidak bisa diselamatkan, ada satu orang yang tenggelam namun masih bisa diselamatkan. Ada yang tertusuk dengan bulu-bulu babi, tersengat dengan ubur-ubur dan tertusuk dengan ikan batu dan ikan kemboha namun kasus tidak di laporkan.

Dengan pengalaman dari kasus-kasus yang terjadi apabila ada yang tetusuk dengan ikan batu penanganan awal yang dilakukan yaitu dengan menempelkan obat 
tradisional di bekas tusukan, bila ada korban tenggelam, warga langsung mengangkat korban dari air dan langsung membalikan badan korban dan menepuk-nepuk belakang atau langsung di bawah di Puskesmas Kuma, namun jarak dari Kampung Kulur ke Kampung Kuma memerlukan waktu sekitar 15 menit sehingga perlu dilakukan tindakan pertolongan pertama.

Berdasarkan kasus-kasus di atas peneliti tertarik untuk meneliti permasalahan tersebut dengan judul “Gambaran Pengetahuan Masyarakat Kampung Kulur II Mengenai Pertolongan Pertama Pada Kejadian Kecelakaan Laut

\section{METODE PENELITIAN}

Penelitian ini menggunakan desain penelitian deskriptif untuk mengetahui pengetahuan masyarakat Kampung Kulur II mengenai pertolongan pertama pada kejadian kecelakaan laut. Penelitian dilaksanakan di Kampung Kulur II Kecamatan Tabukan Tengah pada tanggal 15 Mei sampai dengan 22 Mei 2021.

Populasi dalam penelitian ini adalah masyarakat Kampung Kulur II berjumlah 867 jiwa dengan pengumpulan sampel menurut kriteria-kriteria tertentu. Teknik pengambilan sampel dalam penelitian ini ialah purposive sampel dengan total sampel yang dibutuhkan ada 40 responden. Sugiyono (2015), mengemukakan bahwa ukuran sampel yang layak digunakan dalam penelitian antara 30 sampai dengan 500 orang. Kriteria inklusi pada penelitian ini adalah masyarakat yang bersedia menjadi responden, tinggal disekitar pantai dan yang berusia 20-59 tahun. Klasifikasi menurut WHO di usia 20-59 tahun dianggap sudah dewasa. Kriteria eksklusi yaitu masyarakat yang tidak ada di tempat pada saat penelitian.

Penelitian ini menggunakan variabel tunggal yaitu pengetahuan masyarakat mengenai pertolongan pertama pada kejadian kecelakaan laut. Teknik pengumpulan data dari hasil kuesioner yang sudah dibagikan kepada responden dan dengan melakukan wawancara langsung.

\section{HASIL PENELITIAN}

Dari hasil penelitian yang dilakukan oleh peneliti dengan judul Gambaran Pengetahuan Masyarakat Kampung Kulur II Mengenai Pertolongan Pertama Pada Kejadian Kecelakaan Laut

Hasil pengolahan distribusi data menurut usia, jenis kelamin, pendidikan, pekerjaan dan tingkat pengetahuan. Maka didapatkan hasil sebagai berikut :
1. Usia

Distribusi responden berdasarkan usia dapat dilihat pada tabel berikut :

Tabel 1. Distribusi responden menurut usia

\begin{tabular}{ccc}
\hline Kelompok & \multicolumn{2}{c}{ Jumlah } \\
\cline { 2 - 3 } Usia & Responden & $\begin{array}{c}\text { Presentase } \\
\text { \% }\end{array}$ \\
\hline $\begin{array}{c}20-29 \\
\text { Tahun }\end{array}$ & 13 & 32,5 \\
\hline $\begin{array}{c}30-39 \\
\text { Tahun }\end{array}$ & 10 & 25 \\
\hline $\begin{array}{c}40-49 \\
\text { Tahun }\end{array}$ & 6 & 15 \\
\hline $50-59$ & 11 & 27,5 \\
Tahun & & $\mathbf{1 0 0}$ \\
\hline Total & $\mathbf{4 0}$ & \\
\hline
\end{tabular}

Berdasarkan tabel 1 dapat dilihat dari 40 responden, kelompok usia responden yang terbanyak berusia 20-29 tahun sebanyak 13 responden (32,5\%), dan paling sedikit yang menjadi responden yaitu yang berusia 40-49 tahun sebanyak 6 responden (15\%).

2. Jenis Kelamin

Distribusi responden berdasarkan jenis kelamin dapat dilihat pada tabel berikut :

Tabel 2. Distribusi responden menurut jenis kelamin

\begin{tabular}{ccc}
\hline Jenis & \multicolumn{3}{c}{ Jumlah } \\
\cline { 2 - 3 } Kelamin & Responden & $\begin{array}{c}\text { Presentase } \\
\%\end{array}$ \\
\hline Laki-Laki & 26 & 65 \\
\hline Perempuan & 14 & 35 \\
\hline Total & $\mathbf{4 0}$ & $\mathbf{1 0 0}$ \\
\hline
\end{tabular}

Berdasarkan tabel 2 dapat dilihat dari 40 responden, jenis kelamin laki-laki lebih banyak dari perempuan, dengan jumlah 26 responden (65\%), sedangkan jenis kelamin perempuan hanya 14 responden $(35 \%)$.

3. Pendidikan

Distribusi responden menurut pendidikan dapat dilihat pada tabel berikut:

Tabel 3. Distribusi responden menurut pendidikan

\begin{tabular}{ccc}
\hline Pendidikan & \multicolumn{2}{c}{ Jumlah } \\
\cline { 2 - 3 } & Responden & $\begin{array}{c}\text { Presentase } \\
\text { \% }\end{array}$ \\
\hline SD & 6 & 15 \\
\hline SMP/SLTP & 7 & 17,5 \\
\hline $\begin{array}{c}\text { SMA/SMK } \\
\text { Sederajat }\end{array}$ & 21 & 52,5 \\
\hline D III & & 5 \\
\hline S1 & 4 & 10 \\
\hline Total & 4 & $\mathbf{1 0 0}$ \\
\hline Berdasarkan tabel 3 dapat dilihat dari 40
\end{tabular}

responden, tingkat pendidikan terakhir SMA/SMK lebih banyak dengan jumlah 21 responden $(52,5 \%)$, 
dan D III paling sedikit dengan jumlah 2 responden (5\%).

4. Pekerjaan

Distribusi responden menurut pekerjaan dapat dilihat pada tabel berikut :

Tabel 4. Distribusi responden menurut pekerjaan

\begin{tabular}{ccc}
\hline Pekerjaan & \multicolumn{2}{c}{ Jumlah } \\
\cline { 2 - 3 } & Responden & $\begin{array}{c}\text { Presentase } \\
\text { \% }\end{array}$ \\
\hline IRT & 8 & 20 \\
\hline Petani & 7 & 17,5 \\
Belum & 6 & 15 \\
Bekerja & & \\
\hline Nelayan & 4 & 10 \\
\hline Tenaga & 4 & 10 \\
Honorer & & \\
\hline Buruh & 2 & 5 \\
\hline Karyawan & 2 & 5 \\
Swasta & & \\
\hline Mahasiswa & 2 & 5 \\
\hline Perangkat & 2 & 5 \\
\hline Sopir & 1 & 2,5 \\
\hline Guru & 1 & 2,5 \\
\hline Pelaut & 1 & 2,5 \\
\hline Total & $\mathbf{4 0}$ & $\mathbf{1 0 0}$ \\
\hline Berdary
\end{tabular}

Berdasarkan tabel 4 dapat dilihat dari 40 responden, menunjukkan responden terbanyak memiliki pekerjaan IRT sejumlah 8 responden (20\%), dan yang paling sedikit pekerjaan responden ialah sopir, guru dan pelaut memiliki hasil yang sama 1 responden $(2,5 \%)$

5. Tingkat Pengetahuan

Distribusi responden menurut tingkat pengetahuan dapat dilihat pada tabel beriku :

Tabel 5. Distribusi responden menurut tingkat

\begin{tabular}{ccc}
\multirow{2}{*}{$\begin{array}{c}\text { Pengetahua } \\
\text { n }\end{array}$} & \multicolumn{2}{c}{ Jumlah } \\
\cline { 2 - 3 } & $\begin{array}{c}\text { Responde } \\
\text { n }\end{array}$ & $\begin{array}{c}\text { Presentas } \\
\text { e \% }\end{array}$ \\
\hline Baik & 17 & 42,5 \\
\hline Cukup & 22 & 55 \\
\hline Kurang & 1 & 2,5 \\
\hline Total & 40 & 100 \\
\hline Betahuan
\end{tabular}

responden, tingkat pengetahuan dari 22 responden (55\%) berpengetahuan cukup, berpengetahuan baik 17 responden $(42,5 \%)$ dan 1 responden $(2,5 \%)$ berpengetahuan kurang.

6. Tingkat Pengetahuan Responden Berdasarkan Usia Distribusi tingkat pengetahuan responden berdasarkan usia dapat dilihat pada tabel berikut :

Tabel 6. Distribusi tingkat pengetahuan responden berdasarkan usia

\begin{tabular}{|c|c|c|c|c|c|c|}
\hline \multirow[t]{2}{*}{ Usia } & \multicolumn{5}{|c|}{ Tingkat Pengetahuan } & \multirow{2}{*}{$\begin{array}{c}\text { Respon } \\
\text { den }\end{array}$} \\
\hline & Baik & $\%$ & ukup & $\%$ & Kurang & \\
\hline $\begin{array}{c}20-29 \\
\text { Tahu }\end{array}$ & 6 & 15 & 6 & 15 & 1 & $\begin{array}{c}13 \\
(32,5 \%\end{array}$ \\
\hline
\end{tabular}

\begin{tabular}{cccccccc}
\hline $\mathrm{n}$ & & & & & & 5 & ) \\
\hline $\begin{array}{c}30-39 \\
\text { Tahu }\end{array}$ & 5 & 12 & 5 & 12,5 & - & - & 10 \\
$\mathrm{n}$ & & & & & & & $(25 \%)$ \\
\hline $40-49$ & 3 & 7, & 3 & 7,5 & - & - & 6 \\
Tahu & & 5 & & & & & $(15 \%)$ \\
$\mathrm{n}$ & & & & & & & \\
\hline $50-59$ & 3 & 7, & 8 & 20 & - & - & 11 \\
Tahu & & 5 & & & & & $(27,5 \%$ \\
$\mathrm{n}$ & & & & & & \\
\hline Total & $\mathbf{1 7}$ & $\mathbf{4 2 , 5}$ & $\mathbf{2 2}$ & $\mathbf{5 5}$ & $\mathbf{1}$ & $\mathbf{2}$ & $\mathbf{4 0}$ \\
& & & & & & $\mathbf{1 0 0 \%}$ & $\mathbf{1 0 0}$ \\
& & & & & & $\mathbf{5}$ & \\
\hline
\end{tabular}

Berdasarkan tabel 6 dapat dilihat dari 40 responden, diusia 20-29 tahun lebih banyak memiliki pengetahuan baik yaitu ada 6 responden (15\%), pengetahuan cukup lebih banyak diusia 50-59 tahun ada 8 responden (20\%). Usia 40-49 dan 50-59 tahun paling sedikit berpengetahuan baik ada 3 responden $(7,5 \%)$ dan pengetahuan cukup paling sedikit diusia 40-49 tahun ada 3 responden (7,5\%).

7. Tingkat Pengetahuan Responden Berdasarkan Jenis Kelamin

Distribusi tingkat pengetahuan responden berdasarkan jenis kelamin dapat dilihat pada tabel berikut :

Tabel 7. Distribusi tingkat pengetahuan responden berdasarkan jenis kelamin

\begin{tabular}{|c|c|c|c|c|c|c|c|}
\hline \multirow{2}{*}{$\begin{array}{c}\text { Jenis } \\
\text { Kela } \\
\text { min }\end{array}$} & \multicolumn{6}{|c|}{ Tingkat Pengetahuan } & \multirow{2}{*}{$\begin{array}{c}\text { Respon } \\
\text { den }\end{array}$} \\
\hline & $\begin{array}{c}\text { Bai } \\
\mathbf{k}\end{array}$ & $\%$ & $\begin{array}{r}\text { Cuk } \\
\text { up }\end{array}$ & $\%$ & $\begin{array}{l}\text { Kur } \\
\text { ang }\end{array}$ & $\%$ & \\
\hline $\begin{array}{l}\text { Laki- } \\
\text { laki }\end{array}$ & 10 & 25 & 15 & 37,5 & 1 & $\begin{array}{c}2, \\
5\end{array}$ & $\begin{array}{c}26 \\
(65 \% \\
)\end{array}$ \\
\hline $\begin{array}{l}\text { Pere } \\
\text { mpua } \\
\text { n }\end{array}$ & 7 & 17,5 & 7 & 17,5 & - & - & $\begin{array}{c}14 \\
(35 \% \\
)\end{array}$ \\
\hline Total & 17 & 42,5 & 22 & 55 & $\mathbf{1}$ & $\begin{array}{l}2, \\
5\end{array}$ & $\begin{array}{c}40 \\
(100 \\
\%)\end{array}$ \\
\hline
\end{tabular}

Berdasarkan tabel 7 dapat dilihat dari 40 responden, jenis kelamin laki-laki lebih banyak memiliki pengetahuan baik 10 responden $(25 \%)$ dan cukup 15 responden $(37,5)$, sedangkan perempuan memiliki pengetahuan baik 7 responden $(17,5)$ dan cukup 7 responden $(17,5)$.

8. Tingkat Pengetahuan Responden Berdasarkan Tingkat Pendidikan

Distribusi tingkat pengetahuan responden berdasarkan tingkat pendidikan dapat dilihat pada tabel berikut : 
Tabel 8. Distribusi tingkat pengetahuan responden berdasarkan tingkat pendidikan

\begin{tabular}{|c|c|c|c|c|c|c|}
\hline \multirow{2}{*}{$\begin{array}{l}\text { Pendid } \\
\text { ikan }\end{array}$} & \multicolumn{5}{|c|}{ Tingkat Pengetahuar } & \multirow{2}{*}{$\begin{array}{rr}\begin{array}{r}\text { Respo } \\
\text { nden }\end{array} \\
\% & \end{array}$} \\
\hline & $\begin{array}{l}\text { Ba } \\
\text { ik }\end{array}$ & $\%$ & $\begin{array}{c}\text { Cuk } \\
\text { up }\end{array}$ & & $\begin{array}{c}\mathbf{K} \\
\mathbf{u r} \\
\mathbf{a} \\
\mathbf{n} \\
\mathbf{g}\end{array}$ & \\
\hline SD & 2 & 5 & 4 & 10 & - & $\begin{array}{c}-\quad 6 \\
(15 \% \\
)\end{array}$ \\
\hline $\begin{array}{l}\text { SMP/S } \\
\text { LTP }\end{array}$ & 1 & $\begin{array}{l}2 \\
5\end{array}$ & 6 & 15 & - & $\begin{array}{cc}- & 7 \\
& (17,5 \\
\%)\end{array}$ \\
\hline $\begin{array}{c}\text { SMA/S } \\
\text { MK }\end{array}$ & 12 & 30 & 8 & 20 & 1 & $2,: \begin{array}{c}21 \\
(52,5)\end{array}$ \\
\hline D III & - & - & 2 & 5 & - & $\begin{array}{lc}- & 2 \\
& (5 \%)\end{array}$ \\
\hline S1 & 2 & 5 & 2 & 5 & - & $\begin{array}{c}-\quad 4 \\
(10 \% \\
)\end{array}$ \\
\hline Total & 17 & $\begin{array}{l}42 \\
, 5\end{array}$ & 22 & 55 & 1 & $\begin{array}{cc}2, & 40 \\
& (100 \\
& \%)\end{array}$ \\
\hline
\end{tabular}

Berdasarkan tabel 8 dapat dilihat dari 40 responden, tingkat pendidikan SMA/ SMK lebih banyak memiliki pengetahuan baik 12 responden $(30 \%)$ dan pengetahuan cukup 8 responden (20\%). SMP/ SLTP paling sedikit memiliki pengetahuan baik 1 responden $(2,5 \%)$.

9. Tingkat Pengetahuan Responden Berdasarkan Hasil Kuesioner

Distribusi tingkat pengetahuan responden berdasarkan hasil kuesioner dapat dilihat pada tabel berikut :

Tabel 9. Distribusi tingkat pengetahuan responden berdasarkan hasil kuesioner

\begin{tabular}{cccccccc}
\hline $\begin{array}{c}\text { Aspek } \\
\text { Kuesioner }\end{array}$ & \multicolumn{5}{c}{ Tingkat Pengetahuan } & $\begin{array}{c}\text { Respond } \\
\text { en }\end{array}$ \\
\cline { 2 - 7 } & $\begin{array}{l}\text { Bai } \\
\text { k }\end{array}$ & & & Cu & \multicolumn{1}{c}{$\begin{array}{l}\text { Kuran } \\
\text { g \% }\end{array}$} & \\
\hline $\begin{array}{c}\text { Konsep } \\
\text { Teori }\end{array}$ & 32 & 80 & 8 & 20 & 0 & 0 & $\begin{array}{c}40 \\
(100 \%)\end{array}$ \\
\hline $\begin{array}{c}\text { Penangana } \\
\text { n } \\
\text { Pada }\end{array}$ & 15 & 37,5 & 19 & 47,5 & 6 & 15 & $\begin{array}{c}40 \\
(100 \%)\end{array}$ \\
$\begin{array}{c}\text { Kecelakaan } \\
\text { Laut }\end{array}$ & & & & & & & \\
\hline $\begin{array}{c}\text { Prinsip } \\
\text { BHD } \\
\text { Bantuan } \\
\text { Hidup } \\
\text { Dasar) }\end{array}$ & 11 & 27,5 & 25 & 62,5 & 4 & 10 & $\begin{array}{c}40 \\
(100 \%)\end{array}$ \\
\hline
\end{tabular}

Berdasarkan tabel 9 dapat dilihat hasil kuesioner dari 40 responden berdasarkan ketiga aspek konsep teori, penanganan pada kecelakaan laut dan BHD. Konsep teori paling banyak memiliki hasil baik dengan hasil $32(80 \%)$ responden dan yang paling sedikit memiliki hasil baik pada aspek prinsip bantuan hidup dasar (BHD) 11 (27,5). Hasil wawancara dengan salah satu responden mengatakan bahwa masyarakat belum menerima informasi dari pihak-pihak yang memiliki pengalaman dan pemahaman yang lebih luas pada penaganan kecelakaan laut dan prinsip pemberian bantuan hidup dasar.

\section{PEMBAHASAN}

Berdasarkan hasil penelitian di Kampung Kulur II dapat diketahui bahwa sebagian besar didapatkan 22 responden memiliki pengetahuan cukup dengan hasil presentase $55 \%$.

Pengetahuan masyarakat mengenai pertolongan pertama pada kejadian kecelakaan laut dilihat berdasarkan kuesioner yang sudah dijawab oleh responden yang berisi 20 pernyataan yang terbagi menjadi tiga aspek masing-masing terdiri dari topik konsep teori memiliki 10 pernyataan, penanganan pemberian bantuan hidup dasar (BHD) memiliki 7 pernyataan, dan penanganan pada kecelakaan yang terjadi di laut memiliki 3 pernyataan.

Berdasarkan hasil pernyataan kuesioner dari 40 responden, pengetahuan responden terhadap pertolongan pertama pada kejadian kecelakaan laut termasuk dalam kategori cukup, meskipun hasil wawancara dengan salah satu responden, mengatakan bahwa masyarakat belum menerima informasi berupa sosialisasi atau penyuluhan mengenai pertolongan pertama yang diberikan pada seseorang yang mengalami kecelakaan laut.

Hasanah, Safri, \& Erianti (2019) menyatakan bahwa informasi dan pendidikan sangat mempengaruhi pengetahuan seseorang. Namun dapat dilihat dari hasil penilaian dalam menjawab pernyataan tentang topik konsep teoritis sebagian besar responden menjawab dengan kategori benar. Pengetahuan responden pada aspek penanganan pada kejadian kecelakaan laut dan pada aspek pemberian bantuan hidup dasar (BHD) sebagian responden memiliki pengetahuan yang cukup. Dilihat dari hasil kuesioner responden kurang memahami bagaimana cara melakukan pertolongan.

Pengetahuan tentang bantuan hidup dasar (BHD) sangat penting bagi masyarakat awam karena kejadian kegawatdaruratan dapat di jumpai dimana saja dan kapan saja. Sehingga dapat menjadi bekal untuk menolong orang lain. Bantuan hidup dasar merupakan tindakan yang bertujuan untuk mengembalikan dan mempertahankan fungsi organ vital pada korban henti jantung dan henti napas dengan memberikan 
kompresi dada atau resusitasi jantung paru dan pemberian napas bantuan (Hardisman, 2014).

Pentingnya pemberian informasi dari petugas kesehatan tentang pertolongan pertama pada kecelakaan laut dapat membantu masyarakat dalam mengetahui dan memahami tentang pertolongan pertama yang akan dilakukan saat seseorang mengalami kecelakaan laut. Tingkat pengetahuan penolong berhubungan dengan tingkat Pendidikan, sumber informasi dan keikutsertaan dalam pelatihan Bantuan Hidup Dasar (BHD) (Hidayati, 2020).

Hasil penelitian yang dilakukan berdasarkan kelompok usia, responden dengan usia 20-29 tahun lebih banyak memiliki pengetahuan baik 6 responden $(15 \%)$. Menurut Nursalam dan Pariani, (2003) pada usia 20-30 tahun seseorang telah memiliki kemampuan mental yang diperlukan untuk mempelajari dan menyesuaikan diri pada situasi baru, misalnya mengingat yang dulu pernah dipelajari, penelaran analogis, dan berfikir kreatif. Usia 40-49 tahun dan 50-59 tahun paling sedikit memiliki pengetahuan baik yaitu 3 responden (7,5\%) sedangkan yang memiliki pengetahuan cukup paling banyak diusia 50-59 tahun ada 8 responden (20\%). Usia seseorang mempengaruhi daya ingat dan perilaku yang diperoleh seseorang, semakin tinggi usia seseorang maka daya ingat seseorang akan semakin berkurang (Notoadmojo, 2010).

Hasil penelitian berdasarkan tingkat pendidikan menunjukan bahwa responden terbanyak adalah pendidikan SMA/ SMK 21 responden dengan hasil presentase $(52,5 \%)$ dan paling banyak memiliki pengetahuan baik SMA/ SMK 12 responden (30\%) dari 21 responden $(52,5 \%), \mathrm{S} 1$ berjumlah 4 responden $(10 \%)$ yang memiki pengetahuan baik ada 2 responden $(5 \%)$, sama dengan SD yaitu 2 responden (5\%) yang memiliki pengetahuan baik dari jumlah 6 responden (15\%). Yang paling sedikit memiliki tingkat pengetahuan baik SMP/ SLTP 1 responden $(2,5 \%)$ dari 7 responden $(17,5 \%)$.

Budiman dan Riyanto (2013) mengemukakan bahwa Pengetahuan sangat erat kaitannya dengan pendidikan di mana diharapkan seseorang dengan pendidikan tinggi, orang tersebut akan semakin luas pula pengetahuannya. Namun, perlu ditekankan bahwa seorang yang berpendidikan rendah tidak berarti mutlak berpengetahuan rendah pula. Peningkatan pengetahuan tidak mutlak diperoleh di pendidikan formal, akan tetapi juga dapat diperoleh pada pendidikan nonformal.

Pengetahuan seseorang tentang sesuatu objek juga mengandung dua aspek yaitu aspek positif dan negatif. Kedua aspek inilah yang akhirnya akan menentukan sikap seseorang terhadap objek tertentu. Semakin tinggi tingkat pendidikan belum tentu tingkat pengetahuan seseorang juga akan bertambah. Sebaliknya makin rendah tingkat pendidikan masih memungkinkan untuk mereka bisa menerima informasi dengan baik, sehingga pengetahuan yang dimilikinya juga bisa bertambah (Nursalam dan Pariani, 2001).

Dari hasil yang diperoleh pengetahuan laki-laki dan perempuan memperoleh hasil yang relative seimbang. Ifada (2010) mengemukakan tidak ada hubungan yang bermakna yang bisa dikaitkan antara tingkat pengetahuan seseorang dengan jenis kelaminnya.

Menurut Irwing (2009) dalam Asdiwinata et all (2019), setiap laki-laki maupun perempuan memiliki tingkat pengetahuan yang sama karena akses untuk menerima ilmu pengetahuan atau pendidikan tidak hanya prioritas pada laki-laki melainkan memiliki prioritas yang sama baik perempuan maupun laki-laki dengan demikian apabila informasi dan pengetahuan yang didapatkan baik maka tingkat pengetahuan perempuan maupun laki-laki akan relative sama.

\section{KESIMPULAN}

Berdasarkan tujuan penelitian, hasil penelitian dan pembahasan yang dilakukan secara sistematis terhadap pengetahuan masyarakat Kampung Kulur II Kecamatan Tabukan Tengah Tentang Gambaran Pengetahuan Masyarakat Mengenai Pertolongan Pertama Pada Kecelakaan Laut, menunjukan hasil 55\% masyarakat berpengetahuan cukup.

\section{DAFTAR RUJUKAN}

Asdiwinata, i. N., yundari, a. I. D. H., \& widnyana, i. P. A. (2019). Gambaran tingkat pengetahuan masyarakat terhadap pertolongan pertama pada kecelakaan lalu lintas di banjar buagan, desa pemecutan kelod: description of the public level of knowledge of first aid in traffic accidents in banjar buagan, pemecutan kelod. Bali medika jurnal, 6(1), 58-70. DOI: $\underline{\text { https://doi.org/10.36376/bmj.v6i1.67 }}$

Hardisman, J., (2014). Gawat darurat medis praktik. Gosyen Publishing: Yogyakarta

Hasanah, N. I., Safri, S., \& Erianti, S. (2019). Faktorfaktor yang berhubungan dengan sikap polisi lalu lintas dalam pemberian bantuan hidup dasar (bhd) pada pertolongan pertama kecelakaan lalu lintas di polresta pekanbaru. Al-asalmiya nursing: journal of nursing sciences, 8(2), 70-79. Diakses dari $\underline{\text { http://jurnal.alinsyirah.ac.id/index.php/keperawa }}$ $\underline{\tan }$ 
Hidayati, R. (2020). Tingkat Pengetahuan Masyarakat Tentang Penanganan Henti Jantung di Wilayah Jakarta Utara. NERS Jurnal Keperawatan, 16(1), 10-17.

DOI: $\quad$ https://doi.org/10.25077/njk.16.1.10$\underline{17.2020}$

Ifada, I. (2010). Faktor-faktor yang berhubungan dengan pengetahuan masyarakat mengenai pelayanan kesehatan mata (Doctoral dissertation, Faculty of Medicine). Diambil dari http://eprints.undip.ac.id/23397/

Notoatmodjo, S., (2010). Promosi kesehatan teori dan aplikasinya. Cetakan 2. Rineka Cipta: Jakarta

Nursalam,. Pariani, S., (2001). Pendekatan praktis metodologi riset keperawatan. CV Sagung Seto: Jakarta.
Sugiyono, (2015). Metode penelitian kombinasi (Mix Methods). Alfabeta: Bandung.

Sarana, d., Susilo, d., Darwis, d., \& Pahlevi, d. (2009). Pedoman Pertolongan Pertama. Bandung: Markas Pusat PMI Indonesia. Hal.1

Wastd, D. (2006). Teknik Penyelamatan di Air, Jurnal Ilmiah Kesehatan Olahraga Medikora, diakses 26 Februari 2021, dari :

https://scholar.google.com/scholar?hl=id\&as_sd $\mathrm{t}=0 \% 2 \mathrm{C} 5 \% \mathrm{q}=$ kecelakaan+air+pertolongan $\% \mathrm{oq}$ $=$ kecelakaan+air\#d=gs_qabs\&u=\%23p\%3DvR8 h0xlb364J 
Welembuntu, Manoppo, dan Gobel, Gambaran Pengetahuan Masyarakat...54

\section{POLITEKNIK NEGERI NUSA UTARA}

